Molecules 2009, 14, 2976-2984; doi:10.3390/molecules 14082976

Article

\title{
Azolyacetones as Precursors to Indoles and Naphthofurans Facilitated by Microwave Irradiation with Simultaneous Cooling
}

\author{
Saleh Mohammed Al-Mousawi* and Morsy Ahmed El-Apasery \\ Department of Chemistry, Faculty of Science; University of Kuwait, Safat, 13060, P.O. Box 12613, \\ Kuwait
}

* Author to whom correspondence should be addressed; E-mail: saleh.almousawi@yahoo.com; Tel.: +965-24985547; Fax: +965-24816482

Received: 8 July 2009; in revised form: 30 July 2009 / Accepted: 5 August 2009 /

Published: 11 August 2009

\begin{abstract}
Phthalimide reacted with phenacyl bromide under microwave irradiation to yield phenacyl isoindolidene-1,3-dione (3b), while 3a reacted with phenylhydrazine to yield the phenylhydrazone 4 that was readily converted into indoylphthalimide $\mathbf{8}$. Similarly $N$-benzotriazolylacetone (6a) reacted with phenyl hydrazine to yield the phenylhydrazone 7a that was converted into indoylbenzotriazole 9 . Treatment of 8 with hydrazine hydrate afforded a mixture of phthalhydrazide $\mathbf{1 0}$ and 3-amino-2-methylindole (11). Reacting enaminone 13 with naphthoquinone (14) afforded the aryl naphthofuran 17. The possibility of the formation of the aldehyde $\mathbf{1 8}$ was excluded based on HMQC, which revealed that the carbonyl carbon is not linked to any hydrogen.
\end{abstract}

Keywords: microwave irradiation; aminoindole; naphthofuran; azolylacetone

\section{Introduction}

Azolylketones are versatile reagents and their chemistry has received considerable attention [1-4]. In previous work from our laboratories [5-9], we have investigated possible utility of 2-(2oxopropyl)isoindole-1,3-dione (3a) and 1-benzotriazol-1-yl-propan-2-one (6a) for synthesis of polyfunctional heteroaromatics. In conjunction of this work we report here on utility of compounds 3 and $\mathbf{6}$ as precursors to substituted indoles and naphthofurans. However, we found that the reactions of azolylketones were rather sluggish at room temperature, affording the final naphthofurans in moderate 
yields. During the course of our explorations, we observed that the rate and the yield of these reactions could be greatly improved when performed under microwave irradiation in combination with simultaneous cooling at $30^{\circ} \mathrm{C}$. In this contribution, we would like to disclose the preliminary results of our investigations.

\section{Results and Discussion}

Reacting potassium phthalimide (1) with phenacyl bromide (2b) either by refluxing in dimethylformamide (DMF) for 30 minutes or in microwave oven (MW) at $55{ }^{\circ} \mathrm{C}$ for 10 minutes afforded the phenacyl isoindolidinedione (3b) (cf. Scheme 1).

Scheme 1. Preparation of 2-(2-Oxo-2-phenylethyl)isoindole-1,3-dione.<smiles>O=C1NC(=O)c2ccccc21</smiles>

1<smiles>[X]CC([Y])=O</smiles>

2a, $\mathrm{X}=\mathrm{Cl}, \mathrm{Y}=\mathrm{Me}$

b, $\mathrm{X}=\mathrm{Br}, \mathrm{Y}=\mathrm{Ph}$

MW<smiles>[Y]C(=O)CN1C(=O)c2ccccc2C1=O</smiles>

3a, $\mathrm{Y}=\mathrm{Me}$

b, $\mathrm{Y}=\mathrm{Ph}$

Compound 3a [6,7] reacted with phenylhydrazine under MW at $130{ }^{\circ} \mathrm{C}$ for 20 minutes to yield the phenylhydrazone 4 [7] in 74\% yield, while similar treatment of 3b [10-12] resulted in formation of phthalimide (5) (cf. Scheme 2).

Scheme 2. Preparation of 2-[2-(Phenylhydrazono)propyl]isoindole-1,3-dione.

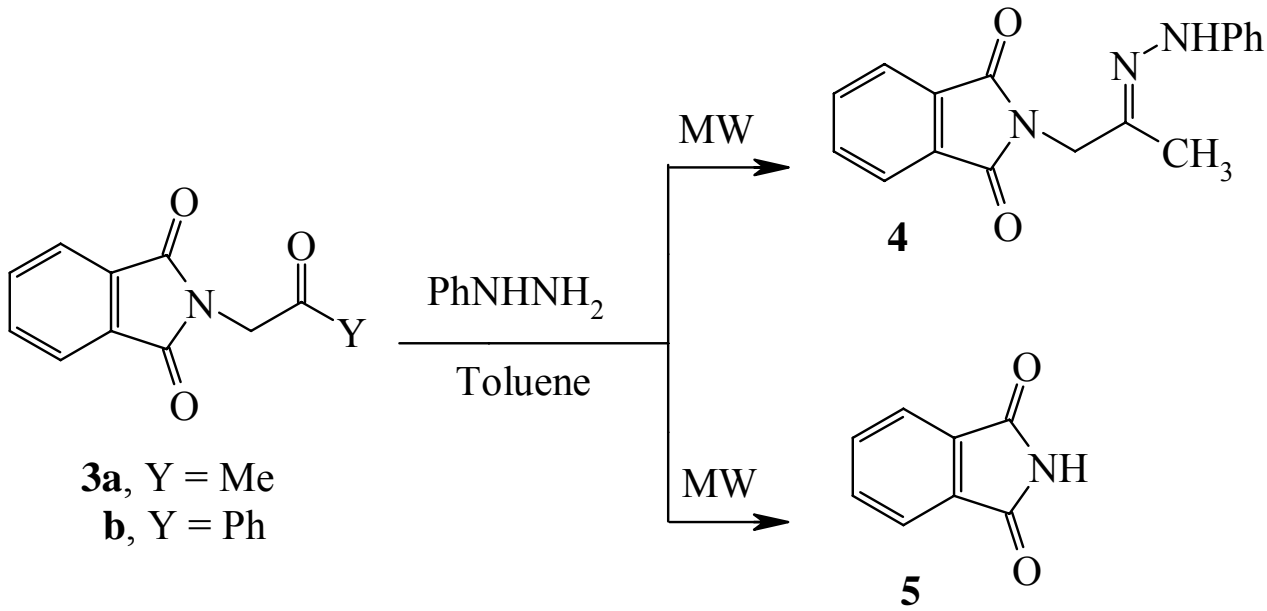

Similarly, $N$-benzotriazolylacetone (6a) reacted with phenylhydrazine under $\mathrm{MW}$ at $130{ }^{\circ} \mathrm{C}$ for 20 minutes to yield the phenylhydrazone 7 a in $89 \%$ yield (cf. Scheme 3 ). 
Scheme 3. Preparation of $N$-(2-Benzotriazol-1-yl-1-methyl-ethylidene)- $N$ '-phenylhydrazine.<smiles>[Y]/C(Cn1nnc2ccccc21)=N\Nc1ccccc1</smiles>
6a, $\mathrm{Y}=\mathrm{Me}$
b, $\mathrm{Y}=\mathrm{Ph}$
7a, $\mathrm{Y}=\mathrm{Me}$
b, $\mathrm{Y}=\mathrm{Ph}$

Heating of $\mathbf{4}$ or $\mathbf{7 a}$ with zinc chloride and a few drops of acetic acid under microwave irradiation at $160{ }^{\circ} \mathrm{C}$ for 30 minutes afforded compounds 8 or 9 in $72 \%$ and $88 \%$ yields, respectively. Despite Katritzky's reports $[13,14]$ that benzotriazole substituents are masked halides, we failed to replace the benzotriazolyl moiety in the formed indole under a variety of conditions. It is of value to report that compound 8 has been previously obtained via pyrolysis of 4,5-disubstituted 1-phthalimido-1,2,3triazoles [15]. Treatment of 8 with hydrazine hydrate under MW at $130{ }^{\circ} \mathrm{C}$ for 20 minutes afforded phthalhydrazide (10) in 85\% yield, along with a product which was identified as 3-amino-2methylindole (11). This amine $\mathbf{1 1}$ has been previously prepared in two steps via nitration of 2-methylindole and subsequent reduction [16] (cf. Scheme 4).

Scheme 4. Synthesis of 1-(2-Methyl-1H-indol-3-yl)-1H-benzotriazole.

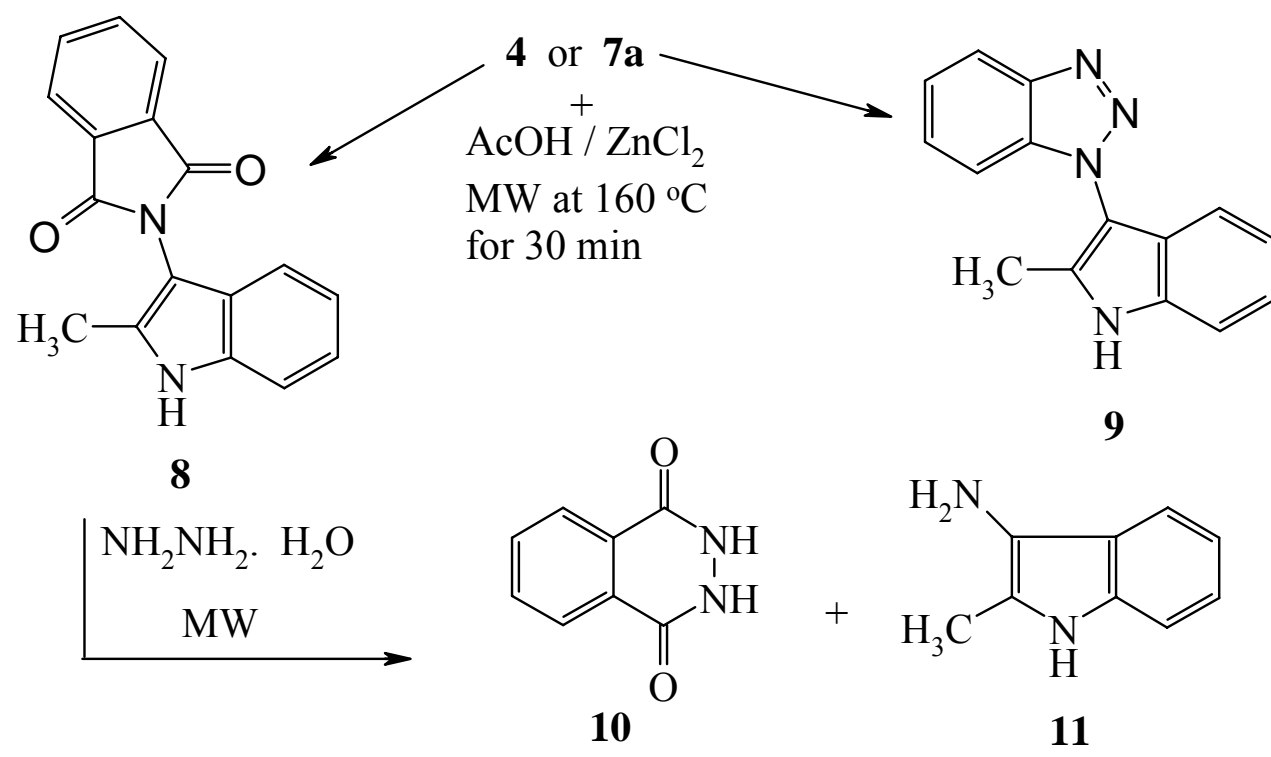

In previous work we have shown that the methylene group in $N$-alkylazolylketones is activated toward electrophiles and that this activity is enhanced by microwave heating [17]. In continuation of this work we report on the synthesis of 2-(4-dimethylamino-2-oxo-3-butenyl)isoindole-1,3-dione as precursor to the title compounds. Thus, condensation of 3a with dimethylformamide dimethyl acetal (DMF-DMA, 12) has afforded enaminone 13 in 76\% and 77\% yields, either by refluxing in xylene for $8 \mathrm{~h}$ or by heating under $\mathrm{MW}$ without solvent at $180{ }^{\circ} \mathrm{C}$ for $20 \mathrm{~min}$, respectively. We decided to investigate the effect of microwave irradiation, keeping the temperature at $30{ }^{\circ} \mathrm{C}$. This should also 
allow us to maintain the maximum power input of $70 \mathrm{~W}$ during the full run of the irradiation. To ensure a correct temperature measurement, a fiber optic sensor was used. Using the same reagent ratios and solvent as these for the reaction run at room temperature, we performed the reaction of enaminone 13 with naphthoquinone (14) under microwave irradiation with simultaneous cooling to $30{ }^{\circ} \mathrm{C}$. The reaction proceeded smoothly, furnishing the corresponding arylnaphthofuran product $\mathbf{1 7}$ in increased yield $(66 \%)$; this is $52 \%$ higher compared to the conventional reaction at room temperature. It is noteworthy that the reactions could be performed using the irradiation power of $70 \mathrm{~W}$ continuously during the whole run, as the high power level was needed to maintain the temperature at $30^{\circ} \mathrm{C}$ because of the efficient external cooling. The differences in yield could be attributed to a lower rate of decomposition of the compounds when using simultaneous cooling. The possibility of the formation of the aldehyde 18 was excluded based on HMQC, which revealed that the carbonyl carbon is not linked to any hydrogen (cf. Scheme 5).

Scheme 5. Synthesis of 2-[2-(5-Hydroxynaphtho[1,2-b]furan-3-yl)-2-oxoethyl]isoindole-1,3-dione.<smiles>CC(=O)CN1C(=O)c2ccccc2C1=O</smiles>

DMFDMA

12<smiles>CN/C=C/C(=O)CN1C(=O)c2ccccc2C1=O</smiles>

13<smiles>O=Cc1c(CN2C(=O)c3ccccc3C2=O)oc2c1cc(O)c1ccccc12</smiles>

18

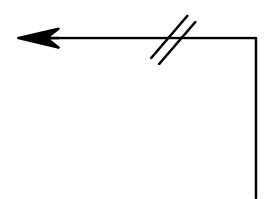

$\rightarrow$

15

14<smiles>O=C(CN1C(=O)c2ccccc2C1=O)c1coc2c1cc(O)c1ccccc12</smiles>

17<smiles>CC(C)C(=O)CN1C(=O)c2ccccc2C1=O</smiles> 


\section{Conclusions}

In summary, we could extend Fisher's indole reaction to enable the synthesis of 2-(2-methyl-1Hindol-3-yl)isoindole-1,3-dione and 1-(2-methyl-1H-indol-3-yl)-1H-benzotriazole using microwave irradiation. It is worthwhile to mention here that thermal and microwave assisted reactions were conducted in different solvents, with the exception of 13, which was prepared by microwave heating without solvent. We have also revealed that the reactions described have proceeded to completion in a much shorter time when irradiated in a focused microwave oven. Moreover, the microwave assisted reactions produced somewhat higher yields than those obtained by conventional heating.

\section{Experimental}

\section{General}

Melting points are uncorrected. All the reactions were conducted under microwave irradiation in heavy-walled Pyrex tubes (capacity $10 \mathrm{~mL}$ ) fitted with PCS caps. Microwave heating was carried out with a single mode cavity Explorer Microwave Synthesizer (CEM Corporation, NC, USA), producing continuous irradiation and equipped with simultaneous external air-cooling system. Compound 17 was prepared in a microwave irradiation experiment which was carried out in a dedicated CEM-DiscoverCoolmate monomode microwave apparatus operating at a frequency of $2.45 \mathrm{GHz}$ with continuous irradiation power from 0 to $300 \mathrm{~W}$. The reaction was carried out in an open $10 \mathrm{~mL}$ double walled glass vial, which was cooled to $10{ }^{\circ} \mathrm{C}$ using a microwave transparent cooling liquid. The temperature was measured with a fiber-optic device inserted into the reaction vessel. IR spectra were recorded in $\mathrm{KBr}$ disks using a Perkin-Elmer System 2000 FT-IR spectrophotometer. ${ }^{1} \mathrm{H}-\mathrm{NMR}(400 \mathrm{MHz})$ and ${ }^{13} \mathrm{C}-\mathrm{NMR}$ (100 MHz) spectra were recorded on a Bruker DPX 400, super-conducting NMR spectrometer in $\mathrm{CDCl}_{3}$ or DMSO as solvent and TMS as internal standard; chemical shifts were reported in $\delta$ units (ppm). Mass spectra were measured on a VG Autospec-Q (high resolution, high performance, tri-sector GC/MS/MS). Microanalyses were performed on a LECO CHNS-932 Elemental Analyzer. Compounds $\mathbf{3 a}, \mathbf{6 a}, \mathbf{b}$ and $\mathbf{7 b}$ have been reported earlier and proven to be identical with the products obtained here $[1,6,7,13,18]$.

\section{2-(2-Oxo-2-phenylethyl)isoindole-1,3-dione (3b)}

Thermal method: A mixture of phthalimide potassium salt $(1.85 \mathrm{~g}, 0.01 \mathrm{~mol})$ and phenacyl bromide $(1.99 \mathrm{~g}, 0.01 \mathrm{~mol})$ in dry DMF $(20 \mathrm{~mL})$ was mixed gently until the exothermic reaction ceased. The mixture was heated for $30 \mathrm{~min}$, filtered and washed with water. The solid product was collected and crystallized from EtOH to give a yield of $95 \%$, mp $160-164{ }^{\circ} \mathrm{C}$ (all data agreed with the published values $[11,12])$.

Microwave method: A mixture of phthalimide potassium salt $(1.85 \mathrm{~g}, 0.01 \mathrm{~mol})$ and phenacyl bromide $(1.99 \mathrm{~g}, 0.01 \mathrm{~mol})$ in dry DMF $(2 \mathrm{~mL})$ was irradiated in focused microwave at $55{ }^{\circ} \mathrm{C}$ for $10 \mathrm{~min}$. The build-up of pressure in the closed reaction vessel was carefully monitored. After the irradiation, the reaction tube was cooled with high-pressure air through a built-in system in the instrument until the 
temperature had fallen below $50{ }^{\circ} \mathrm{C}$. The crude product was poured onto water and the solid product, so formed, was collected by filtration and crystallized from EtOH to give a $68 \%$ yield of the target compound.

\section{General method for preparation of compounds $\mathbf{4}$ and $\mathbf{7 a}$}

A dried heavy-walled Pyrex tube containing a small stir bar was charged with compounds 3a or 6a $(0.01 \mathrm{~mol})$, phenylhydrazine $(1.08 \mathrm{~g}, 0.01 \mathrm{~mol}))$ and ethanol $(2 \mathrm{~mL})$ or toluene $(2 \mathrm{~mL})$. The tube containing the reaction mixture was fitted with a PCS cap and then it was exposed to microwave irradiation at $130{ }^{\circ} \mathrm{C}$ for $20 \mathrm{~min}$. The solvent was removed and the residue, when cooled, deposited a solid, which was crystallized from ethanol.

2-[2-(Phenylhydrazono)propyl]isoindole-1,3-dione (4): $\mathrm{mp} 158-160{ }^{\circ} \mathrm{C}$; IR $\left(\mathrm{KBr}, \mathrm{cm}^{-1}\right): 3321(\mathrm{NH})$, 1774 (CO); MS (EI) m/z: (\%) 293 (M+, 100\%); ${ }^{1} \mathrm{H}-\mathrm{NMR}\left(\mathrm{DMSO}-d_{6}\right): \delta=1.90\left(\mathrm{~s}, 3 \mathrm{H}, \mathrm{CH}_{3}\right), 4.37$ (s, 2H, $\left.\mathrm{CH}_{2}\right), 6.85$ (t, 1H, J = 7.2 Hz, phenyl-H), $6.72(\mathrm{~d}, 2 \mathrm{H}, \mathrm{J}=7.8 \mathrm{~Hz}$, phenyl-H), 6.94 (t, 2H, J = 7.8 $\mathrm{Hz}$, phenyl-H), 7.87-7.88 (m, 2H, phthalmidyl-H), 7.92-7.93 (m, 2H, phthalmidyl-H) 8.90 (s, 1H, NH), Anal. Calcd. for $\mathrm{C}_{17} \mathrm{H}_{15} \mathrm{~N}_{3} \mathrm{O}_{2}$ (293.32): C, 69.61; H, 5.15; N, 14.33. Found: C, 69.24; H, 5.36; N, 13.94.

$N$-(2-Benzotriazol-1-yl-1-methyl-ethylidene)- $N^{\prime}$-phenylhydrazine (7a): $\mathrm{mp} 128-130{ }^{\circ} \mathrm{C}$; IR $\left(\mathrm{KBr}, \mathrm{cm}^{-1}\right)$ : $3359(\mathrm{NH}), \mathrm{LC}-\mathrm{MS} 265(\mathrm{M}+, 58 \%){ }^{1} \mathrm{H}-\mathrm{NMR}$ (DMSO-d $\left.)_{6}\right): \delta=1.84\left(\mathrm{~s}, 3 \mathrm{H}, \mathrm{CH}_{3}\right), 5.53\left(\mathrm{~s}, 2 \mathrm{H}, \mathrm{CH}_{2}\right)$, $6.68(\mathrm{t}, 1 \mathrm{H}, \mathrm{J}=7.2 \mathrm{~Hz}$, arom-H), $6.96(\mathrm{~d}, 2 \mathrm{H}, \mathrm{J}=8.4 \mathrm{~Hz}$, arom-H), 7.11 (t, 2H, J = 7.6 Hz, arom-H), 7.39 (t, 1H, J = 7.2 Hz, arom-H), 7.53 (t, 1H, J = 7.2 Hz, arom-H), 7.79 (d, 1H, J = 8.4 Hz, arom-H), $8.07\left(\mathrm{~d}, 1 \mathrm{H}, \mathrm{J}=8.4 \mathrm{~Hz}\right.$, arom-H), $9.10(\mathrm{~s}, 1 \mathrm{H}, \mathrm{NH}),{ }^{13} \mathrm{C}-\mathrm{NMR}\left(\mathrm{DMSO}-d_{6}\right): \delta=13.61\left(\mathrm{CH}_{3}\right), 54.24$ $\left(\mathrm{CH}_{2}\right), 110.81,112.42,118.80,119.18,123.94,127.34,128.79,133.23,138.61,145.32,145.65$.

\section{General method for preparation of compounds $\mathbf{8}$ and $\mathbf{9}$}

A dried heavy-walled Pyrex tube containing a small stir bar was charged with compounds $\mathbf{4}$ or 7a $(0.01 \mathrm{~mol})$, zinc chloride $(1.36 \mathrm{~g}, 0.01 \mathrm{~mol})$ and acetic acid $(2 \mathrm{~mL})$. The tube was exposed to $\mathrm{MW}$ at $160{ }^{\circ} \mathrm{C}$ for $30 \mathrm{~min}$. The crude product was poured onto water, and the solid product, so formed, was collected by filtration and crystallized from toluene.

2-(2-Methyl-1H-indol-3-yl)isoindole-1,3-dione (8): mp 222-224 ${ }^{\circ} \mathrm{C}$; IR (KBr, $\left.\mathrm{cm}^{-1}\right): 3278(\mathrm{NH})$, MS (EI) $\mathrm{m} / \mathrm{z}$ : (\%) $276(\mathrm{M}+, 100 \%) ;{ }^{1} \mathrm{H}-\mathrm{NMR}\left(\mathrm{DMSO}-d_{6}\right): \delta=2.77\left(\mathrm{~s}, 3 \mathrm{H}, \mathrm{CH}_{3}\right), 6.95(\mathrm{t}, 1 \mathrm{H}, \mathrm{J}=7.2 \mathrm{~Hz}$, indolyl $-\mathrm{H}), 7.07(\mathrm{t}, 1 \mathrm{H}, \mathrm{J}=7.2 \mathrm{~Hz}$, indolyl $-\mathrm{H}), 7.23(\mathrm{~d}, 1 \mathrm{H}, \mathrm{J}=8.0 \mathrm{~Hz}$, indolyl $-\mathrm{H}), 7.36(\mathrm{~d}, 1 \mathrm{H}$, $\mathrm{J}=8.0 \mathrm{~Hz}$, indolyl-H), 7.91-7.93 (m, 2H, phthalmidyl-H), 7.98-8.00 (m, 2H, phthalmidyl-H) 11.41 (s, $1 \mathrm{H}, \mathrm{NH}),{ }^{13} \mathrm{C}-\mathrm{NMR}$ (DMSO-d $): \delta=11.07\left(\mathrm{CH}_{3}\right), 103.74,111.13,117.09,119.28,120.93,123.43$, $124.75,125.36,128.24,128.93,131.85,133.27,133.95$, 134.65, 163.49. Anal. Calcd. for $\mathrm{C}_{17} \mathrm{H}_{12} \mathrm{~N}_{2} \mathrm{O}_{2}$ (276.29): C, 73.90; H, 4.38; N, 10.14. Found: C, 73.83; H, 4.38; N, 10.05.

1-(2-Methyl-1H-indol-3-yl)-1H-benzotriazole (9): $\mathrm{mp}>300{ }^{\circ} \mathrm{C}$; IR (KBr, $\left.\mathrm{cm}^{-1}\right): 3280(\mathrm{NH}), \mathrm{MS}(\mathrm{EI})$ $\mathrm{m} / \mathrm{z}:(\%) 248(\mathrm{M}+, 30 \%) ;{ }^{1} \mathrm{H}-\mathrm{NMR}\left(\mathrm{DMSO}_{6}\right): \delta=2.30\left(\mathrm{~s}, 3 \mathrm{H}, \mathrm{CH}_{3}\right), 7.03(\mathrm{t}, 1 \mathrm{H}, \mathrm{J}=7.2 \mathrm{~Hz}$, arom$\mathrm{H}), 7.07(\mathrm{~d}, 1 \mathrm{H}, \mathrm{J}=7.8 \mathrm{~Hz}$, arom-H), $7.16(\mathrm{t}, 1 \mathrm{H}, \mathrm{J}=8.4 \mathrm{~Hz}$, arom-H), 7.49-7.75 (m, 4H, arom-H), 
$7.56\left(\mathrm{t}, 1 \mathrm{H}, \mathrm{J}=7.8 \mathrm{~Hz}\right.$, arom-H), $8.16\left(\mathrm{~d}, 1 \mathrm{H}, \mathrm{J}=8.4 \mathrm{~Hz}\right.$, arom-H), $11.75(\mathrm{~s}, 1 \mathrm{H}, \mathrm{NH}),{ }^{13} \mathrm{C}-\mathrm{NMR}$ $\left(\right.$ DMSO- $_{6}: \delta=11.33\left(\mathrm{CH}_{3}\right), 109.38,111.05,112.10,116.33,119.21,120.02,120.67,122.20,124.70$, 128.20. 131.65, 134.10, 134.51, 145.49 .

\section{2-Methyl-1H-indol-3-ylamine (11)}

A mixture of compound $8(2.76 \mathrm{~g}, 0.01 \mathrm{~mol})$ and hydrazine hydrate $(1.43 \mathrm{~g}, 0.02 \mathrm{~mol})$ in EtOH $\left(3 \mathrm{~mL}\right.$ ) was irradiated by focused microwave at $130{ }^{\circ} \mathrm{C}$ for $20 \mathrm{~min}$. The solid product, so formed, was collected by filtration to separate the side product [phthalhydrazide (10)]. The filtrate was evaporated under vacuum to remove the solvent and the product $\mathbf{1 1}$ was isolated using column chromatography $\left(\right.$ EtOAc $\left.-\mathrm{CHCl}_{2}\right)$ (all data were in agreement agreed with the published values [16]).

2-(4-Dimethylamino-2-oxobut-3-enyl)isoindole-1,3-dione (13)

Thermal method: A mixture of phthalimidoacetone (2.03 g, $0.01 \mathrm{~mol})$ and DMF-DMA (1.19 g, $0.01 \mathrm{~mol}$ ) in xylene $(5 \mathrm{~mL})$ was heated under reflux for $8 \mathrm{~h}$. The solid product was collected by filtration and crystallized from $\mathrm{EtOH}$. The reaction gave yellow crystals, yield $(76 \%), \mathrm{mp} 159-162{ }^{\circ} \mathrm{C}$ (literature mp $155^{\circ} \mathrm{C}$ [18]); IR (KBr) $v 1769$ (CO), 1714 (CO), 1660 (CO) $\left(\mathrm{cm}^{-1}\right)$; ${ }^{1} \mathrm{H}-\mathrm{NMR}$ (DMSO$\left.d_{6}\right): \delta(\mathrm{ppm}) 2.72\left(\mathrm{~s}, 3 \mathrm{H}, \mathrm{CH}_{3}\right), 3.05\left(\mathrm{~s}, 3 \mathrm{H}, \mathrm{CH}_{3}\right), 4.40\left(\mathrm{~s}, 2 \mathrm{H}, \mathrm{CH}_{2}\right), 5.04(\mathrm{~d}, 1 \mathrm{H}, J=12 \mathrm{~Hz}, \mathrm{CH}), 7.61$

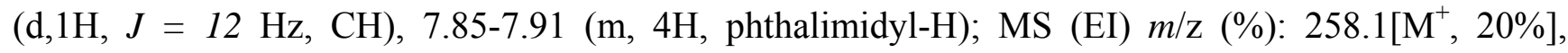
160(20), 76(10); Anal. Calcd.. for $\mathrm{C}_{14} \mathrm{H}_{14} \mathrm{~N}_{2} \mathrm{O}_{3}$ : C, 65.11; H, 5.46; N, 10.85; Found: C, 65.18; H, 5.44; $\mathrm{N}, 10.76$.

Microwave method: A mixture of phthalimidoacetone (2.03 g, $0.01 \mathrm{~mol})$ and DMF-DMA (1.19 g, 0.01 mol) was irradiated by focused microwave at $180{ }^{\circ} \mathrm{C}$ for $20 \mathrm{~min}$. The build-up of pressure in the closed reaction vessel was carefully monitored. After the irradiation, the reaction tube was cooled with highpressure air through a built-in system in the instrument until the temperature had fallen below $50{ }^{\circ} \mathrm{C}$. The solid product, so formed, was collected by filtration and crystallized from EtOH to give a $77 \%$ yield of the target compound.

\section{2-[2-(5-Hydroxynaphtho[1,2-b] furan-3-yl)-2-oxoethyl] isoindole-1,3-dione (17)}

Thermal method: A mixture of compound 13 (2.58g, $0.01 \mathrm{~mol})$ and naphthoquinone $(1.54 \mathrm{~g}, 0.01 \mathrm{~mol})$ was dissolved in glacial acetic acid $(10 \mathrm{~mL})$, then stirred over night at room temperature. The so formed crystals were collected by filtration and crystallized from dioxane. This compound was obtained in yield (52\%). mp 301-303 ${ }^{\circ} \mathrm{C}$; IR (KBr) $\left(\mathrm{cm}^{-1}\right)$ : $3309(\mathrm{OH}), 1776(\mathrm{CO}), 1722(\mathrm{CO}), 1666$ (CO); ${ }^{1} \mathrm{H}-\mathrm{NMR}\left(\mathrm{DMSO}_{6}\right): \delta 5.17\left(\mathrm{~s}, 2 \mathrm{H}, \mathrm{CH}_{2}\right.$ ), 7.45 (s, 1H, H-4), 7.58 (t, 1H, J=8.4Hz, H-7), 7.70 (t, 1H, J=8.4Hz, H-8), 7.91-7.92 (m, 1H, H-14), 7.97-7.98 (m, 1H, H-13), 8.23 (d, 1H, J=8.4Hz, H-9), 8.25 (d, $1 \mathrm{H}, J=8.4 \mathrm{~Hz}, \mathrm{H}-6), 9.31$ (s, $1 \mathrm{H}, \mathrm{H}-2), 10.34$ (s, $1 \mathrm{H}, \mathrm{OH}) ;{ }^{13} \mathrm{C}-\mathrm{NMR}$ (DMSO-d $)$ ): $\delta 188.71(\mathrm{C}-$ 10), 167.99 (C-12), 153.74 (C-2), 151.65 (C-5), 145.02 (C-9b), 135.28 (C-14), 132.02 (C-12a), 128.01 (C-8), 125.61 (C-7), 123.97 (C-5a), 123.89 (C-13), 123.80 (C-6), 121.19 (C-9a), 120.28 (C-3a), 120.08 (C-3), 119.85 (C-9), 100.12 (C-4), $45.23\left(\mathrm{CH}_{2}, \mathrm{C}-11\right)$; MS (EI) m/z (\%) = $371\left[\mathrm{M}^{+}\right]$; Anal. Calcd. for $\mathrm{C}_{22} \mathrm{H}_{13} \mathrm{NO}_{5}$ (371.35); C, 71.16; H, 3.53; N, 3.77. Found C, 71.14; H, 3.65; N, 3.95. 
Microwave method: A mixture of compound 13 (2.58 g, $0.01 \mathrm{~mol})$, naphthoquinone (1.54 g, $0.01 \mathrm{~mol})$, and glacial acetic acid $(1 \mathrm{~mL})$ was irradiated at $30^{\circ} \mathrm{C}$ for $5 \mathrm{~min}$, continuously at the maximum power of $70 \mathrm{~W}$. After completion of the reaction the solvent was evaporated. The crude product was then collected by filtration and crystallized from dioxane to give a $66 \%$ yield of 17 .

\section{Acknowledgments}

The authors are grateful to Kuwait University, Research Administration for financial support through project SC 05 / 06. Analytical facilities provided by SAF projects \# GS 01/01 \& GS 03/01 are greatly appreciated.

\section{References}

1. Al-Saleh, B.; Abdelkhalik, M.M.; El-Apasery, M.A.; Elnagdi, M.H. N-azolylmethyl ketones as building blocks in heterocyclic synthesis: Synthesis of new polyfunctionally substituted azolylarylazophenols, azolylpyridones and azolylthiophenes. J. Heterocyclic Chem. 2003, 40, 171-175.

2. Al-Saleh, B.; Behbehani, H.; El-Apasery, M.A.; Einagdi, M.H. Enaminones as building blocks in heterocyclic synthesis. Synthesis of polyfunctionally substituted 3-azolylpyridines and azolylazoloazines by thermal and microwave heating. J. Chem. Res. 2004, 8, 575-577.

3. Al-Mousawi, S.; Abdel-Khalik, M.M.; El-Sherbiny, S.; John, E.; Elnagdi, M.H. Studies with enaminones: reactivity of 1,5-disubstituted-1,4-pentadien-3-ones toward electrophilic reagents. A novel route to azolylazines, benzofuranals, pyranones. J. Heterocycl. Chem. 2001, 38, 949-953.

4. Al-Naggar, A.; Abdel-Khalik, M.M.; Elnagdi, M.H. Benzotriazol-1-yl-acetone as a building block in heterocyclic chemistry: A route to benzotriazolylpyridazines, benzotriazolyl-phthalazines and benzotriazolylpyrazolo [5,1-c]-1,2,4-triazines. J. Chem. Res. (s) 1999, 11, 648-649, (M), 2801-2810.

5. Al-Saleh, B.; El-Apasery, M.A. Studies with condensed aminothiophenes: Further investigation on the reactivity of condensed aminothiophenes toward electron poor olefins and acetylenes under microwave heating. J. Heterocycl. Chem. 2006, 43, 559-564.

6. Al-Mousawi, S.; John, E.; Al-Kandery, N. Studies with enaminones: Synthesis and chemical reactivity of 2-(4-dimethylamino-2-oxobut-3-enyl)-isoindole-1,3-dione and of 4-(4-dimethylamino-2-oxobut-3-enyloxy)-2H-phthalazin-1-one. J. Heterocycl. Chem. 2004, 41, 381-385.

7. Al-Omran, F.; El-Khair, A.A. Heterocyclic synthesis via enaminones: Novel synthesis of (1H)pyridin-2-one, pyrazolo[1,5-a]pyrimidine and isoxazole derivatives incorporating a Nmethylphthalimide and their biological evaluation. J. Heterocycl. Chem. 2005, 42, 307-312.

8. Al-Omran, F.; El-Khair, A.A. 2-(3-Arylhydrazono-3-formyl-2-oxopropyl)-1H-isoindole-1,3(2H)dione in heterocyclic synthesis. Novel derivatives of pyridazin-6 $(1 \mathrm{H})$-one, pyridazin-6 $(1 \mathrm{H})$-imine, and pyrazolo[5,1-c] $[1,2,4]$ triazine incorporating an $\mathrm{N}$-(2-oxoethyl)phthalimide moiety. J. Chem. Res. 2006, 1, 6-9.

9. Al-Mousawi, S.M.; El-Apasery, M.A.; Al-Kanderi, N.H. Microwave-assisted organic synthesis: The Gabriel approach as a route to new pyrazolylhydrazonoazoles. ARKIVOC 2008, 16, 268-278. 
10. De Paulis, T.; Hemstapat, K.; Chen, Y.; Zhang, Y.; Saleh, S.; Alagille, D.; Baldwin, R.M.; Tamagnan, G.D.; Conn, P.J. Substituent effects of N-(1,3-diphenyl-1H-pyrazol-5-yl)benzamides on positive allosteric modulation of the metabotropic glutamate-5 receptor in rat cortical astrocytes. J. Med. Chem. 2006, 49, 3332-3344.

11. Sun, J.; Yan, C. Catalytic synthesis of $\mathrm{N}$-alkylphthalimides under microwave irradiation. Huaxue Yanjiu 2002, 13, 39-40; [Chem. Abstr. 138: 187594].

12. Goossen, L.J.; Ghosh, K. Palladium-catalyzed synthesis of aryl ketones from boronic acids and carboxylic acids activated in situ by pivalic anhydride. Eur. J. Org. Chem. 2002, 19, 3254-3267.

13. Katritzky, A.R.; Wrobel, L.; Savage, G.P.; Deyrup-Drewniak, M. The formation of ketones by a reaction equivalent to R- + R'COCH2+ R'COCH2R. Aust. J. Chem. 1990, 43, 133-139.

14. Katritzky, A.R.; Wu, J.; Wrobel, L.; Rachwal, S.; Steel, P.J. Novel conversions of benzotriazol-1ylmethyl derivatives. Acta Chem. Scand. 1993, 47, 167-175.

15. Anderson, D.J.; Gilchrist, T.L.; Gymer, G.E.; Rees, C.W. Reactive intermediates. XXII. Formation of $2 \mathrm{H}$-azirines by oxidation of $\mathrm{N}$-aminophthalimide in the presence of alkynes. $J$. Chem. Soc. Perk. Trans.1 1973, 6, 550-555.

16. Bahekar, R.H.; Jain, M.R.; Goel, A.; Patel, D.N.; Prajapati, V.M.; Gupta, A.A.; Jadav, P.A.; Patel, P.R. Design, synthesis, and biological evaluation of substituted-N-(thieno[2,3-b]pyridin-3-yl)guanidines, $\mathrm{N}-(1 \mathrm{H}-$ pyrrolo[2,3-b]pyridin-3-yl)-guanidines, and $\mathrm{N}-(1 \mathrm{H}$-indol-3-yl)-guanidines. Bioorg. Med. Chem. 2007, 15, 3248-3265.

17. Al-Mousawi, S.M.; El-Apasery, M.A.; Elnagdi, M.H. Studies with condensed aminothiophenes: Microwave assisted cycloaddition reactions of thieno[3,4-d]pyridazinone and thieno[3,4c] quinolinone. Heterocycles 2008, 75, 1151-1161.

18. Hassanien, A.A.; Ghozlan, S.A.S.; Elnagdi, M.H. Studies with functionally substituted methylbenzotriazoles: Novel synthesis of functionally substituted pyrazolo[5,1-c]-1,2,4-triazines benzotriazol-1-yl, 1-pyrazol-4-yl benzotriazoles and 1-isoxazol-4-yl benzotriazoles. J. Chin. Chem. Soc. 2004, 51, 575-579.

Sample Availability: Samples of the compounds 1-17 are available from the authors.

(C) 2009 by the authors; licensee Molecular Diversity Preservation International, Basel, Switzerland. This article is an open-access article distributed under the terms and conditions of the Creative Commons Attribution license (http://creativecommons.org/licenses/by/3.0/). 